\title{
Una hermenéutica
} contemporánea de la condición paradójica del hombre cifrada en la condición trágica en el ensayo: "El reflejo de lo trágico antiguo en lo trágico moderno", de Søren Kierkegaard

\section{A contemporary hermeneutic of the paradoxical condition of man encrypted in the tragic condition in the essay: "The reflection of the ancient tragic in the modern tragic", by Søren Kierkegaard}

\section{Berenice Jasso Barranco*}

Universidad Iberoamericana, Ciudad de México, México berejasso@outlook.com 


\title{
Resumen
}

El presente escrito pretende esbozar a través de la hermenéutica aspectos de la condición humana trágica como aislamiento, duda, angustia, asimilación trágica, afirmación paradójica y amor. Todos éstos, vistos en su dimensión anímica, desarrollados por Kierkegaard en el ensayo "El reflejo de lo trágico antiguo en lo trágico moderno" contenido en $O$ lo uno o lo otro, para develar la condición paradójica del hombre cifrada en lo trágico kierkegaardiano y evaluar la actualidad de las categorías kierkegaardianas para leer lo trágico contemporáneo mediante el diálogo con filósofos como Steiner, Heidegger, Derrida, Žižek y Butler.

PALABras Clave: condición humana trágica, condición humana paradójica, aislamiento, duda, angustia, reflexión, asimilación y amor.

\begin{abstract}
:
This paper intends to outline hermeneuticall aspects of the tragic human condition: isolation, doubt, anguish, tragic assimilation, paradoxical affirmation, and love. All these aspects seen especially in their animistic dimension, developed by Kierkegaard in the essay "The reflection of the ancient tragic in the modern tragic" contained in Either/or, to unveil the paradoxical condition of man encrypted in the Kierkegaardian tragic and evaluate the relevance of such Kierkegaardian categories to read the contemporary tragic through dialogue with contemporary philosophers such as Steiner, Heidegger, Derrida, Žižek and Butler.
\end{abstract}

KEYWORDS: ragic human condition, paradoxical human condition, isolation, doubt, anguish, reflection, assimilation, and love.

Recepción 08-01-21 / Aceptación 01-03-21 
* Egresada de la maestría en Filosofía de la Universidad Iberoamericana Ciudad de México; profesora de la licenciatura en Enseñanza y el aprendizaje de español en la educación secundaría y de la maestría en Intervención docente, de la Escuela Normal de Atlacomulco, Profesora Evangelina Alcántara Díaz. 


\section{Introducción}

Una aproximación hermenéutica parece un camino apropiado para adentrarse a la obra del filósofo danés Søren Kierkegaard, quien utilizó seudónimos en las obras no firmadas con su nombre para mantener una comunicación existencial con el lector, pues su objetivo era comunicarse, directa e indirectamente, con la alteridad desde una perspectiva fragmentaria mediante herramientas tanto literarias como filosóficas. Así, la labor cuidadosa de interpretación tiene una doble función: la exégesis del texto y la hermenéutica del sujeto. En la dialéctica con la obra surgen claves interpretativas que permiten comprender en la exégesis no sólo la obra, sino también la existencia, al recobrar contemporaneidad, pues como refiere Žižek:

El único modo de ser fiel a una obra clásica es asumir ese riesgo; evitarlo, manteniéndose fiel a la letra de la tradición, es la forma más segura de traicionar el espíritu de la pieza. Dicho de otro modo, la única forma de mantener viva una obra clásica es tratarla como si fuese una obra abierta, orientada permanentemente hacia el futuro, o, por usar una metáfora empleada por Walter Benjamin, actuar como si la obra clásica fuera una película cuyo revelador solo ha sido inventado con posterioridad, de manera que únicamente en la actualidad podemos obtener la imagen completa. ${ }^{1}$

O lo uno o lo otro es una obra publicada en 1843, en donde se hace una reflexión de la fenomenológica de los estadios estético y ético, los cuales tienen como horizonte el estadio religioso, otro elemento de la complejidad del trabajo hermenéutico de la obra kierkegaardiana. Su comunicación es indirecta y aparece como editor Víctor Eremita, el significado de 
Eremita, refiere a una persona que vive sola en un sitio deshabitado, dedicada a la oración y el sacrificio.

"El reflejo de lo trágico antiguo en lo trágico moderno" contenido en el libro, y cuyo autor es el esteta A, explora un aspecto del estadio estético angular del pensamiento kierkegaardiano: la relatividad subjetiva, como la nombra, y sugiere la posibilidad de asimilarla como parte de la constitución de la verdad subjetiva, o anularla mediante el aislamiento.

En este ensayo se despliegan múltiples conceptos y categorías que se pueden estudiar desde diversas perspectivas, pero nos focalizaremos en interpretar la comprensión del esteta A respecto a la condición humana contenida en su visión de lo trágico. Para él, lo trágico asimilado en la antigüedad griega mantiene su estatuto ontológico en la modernidad. Así, da nuevas claves para leer lo trágico moderno en las que atisba la condición paradójica del hombre.

La disertación se dividirá siguiendo el texto kierkegaardiano: primero, se seleccionaron algunas categorías mediante las cuales se analiza el reflejo y la diferencia entre lo trágico antiguo y lo trágico moderno: la duda, el aislamiento, la responsabilidad, la asimilación y el estado de ánimo trágico. Después, se toman otras categorías con las cuales el esteta A construye su Antígona moderna: reflexión, angustia, el amor como estado de ánimo y la acción trágica que su heroína es capaz de llevar sin sustento. Finalmente, se planteará la implicación de la condición humana paradójica cifrada en lo trágico, y su recepción contemporánea.

Las preguntas que conducirán el texto son las siguientes: ¿ El ensayo "El reflejo de lo trágico antiguo en lo trágico moderno" es una crítica al ocultamiento de lo trágico en la modernidad? ¿cuál es el papel de lo anímico en la constitución de lo trágico?, ¿en qué medida el giro animico planteado por Kierkegaard mediante las categorías cifradas en el pathos trágico permite una hermenéutica de la existencia moderna y contemporánea? 
Estoy comenzando a sentir la embriaguez en que me sumerge esta vida agitada y tumultuosa. La multitud de objetos que pasan ante mis ojos, me causan vértigo. De todas las cosas que me impresionan, no hay ninguna que cautive mi corazón, aunque todas juntas perturben mis sentidos, haciéndome olvidar quién soy y a quién pertenezco.

Rousseau

Se habla desde hace mucho tiempo de la superficialidad de nuestra época; yo creo que ya ha llegado la hora de que se hable un poco de su melancolía, con lo que las cosas quedarian más claras. ¿No es acaso la melancolía el vicio de la época? ¿No es ella la que rebota incluso bajo su risa superficial? ¿No es la melancolía la que nos ha robado la fuerza y el coraje de mandar y el coraje de obedecer, la fuerza para la acción y la confianza en la esperanza? Kierkegaard ${ }^{3}$

¿Cómo no temblar? Derrida

\section{Pensar la diferencia y el reflejo de lo trágico antiguo en lo trágico moderno mediante la duda, el aislamiento, la responsabilidad, la asimilación y el estado de ánimo trágico}

El Odiseo de Homero, tras haber sobrevivido diez años a la guerra de Troya, emprende su viaje de vuelta a casa. Desde el inicio de su travesía es ayudado por la diosa Atenea para librar múltiples problemas que alargan su viaje una década. En el camino llega a la isla de la ninfa Calipso quien 
se enamora de él y le ofrece la inmortalidad a cambio de quedarse con ella; pero Odiseo no podía olvidar Ítaca, así que los dioses la obligaron a dejarlo ir. Éste fue sólo uno de muchos obstáculos que enfrentó antes de volver: la furia de Poseidón, el descenso al Hades, la seducción del canto de las sirenas, descifrar a Hermes, velarse como mendigo y lograr que los suyos lo reconocieran. Mas fue su conato por volver a casa lo que lo sostuvo hasta lograrlo.

2700 años después, el Odiseo de Borges en la figura del tribuno Marco Flaminio, acuartelado en Berenice frente al Mar Rojo tras su derrota, se lanza a descubrir la secreta ciudad de los inmortales. En el nuevo laberinto del corazón humano que teje Borges en "El Inmortal", el personaje busca un río secreto que purificaba de la muerte a los hombres, en una ciudad relatada por un jinete del oriente; así, coloca al tribuno dentro del canto de la ninfa de la antigua Odisea para mostrar que, mientras el griego renuncia a la inmortalidad por su deseo de volver a casa, Marco Flaminio, tras experimentar la enormidad del horror, el sufrimiento y la derrota, instala la inmortalidad como meta. Meta trazada para el hombre moderno y contemporáneo como horizonte de la ciencia, la filosofía y la existencia. Con ello, se aspira a controlar, o más bien borrar, el azar, la contingencia y el sufrimiento, es decir, desaparecer la condición humana y la posibilidad de ser afectado. Resulta interesante que en la ficción de Borges, una vez lograda la inmortalidad, el tribuno experimenta tedio, ansiedad y desesperación, por lo que redirecciona su tarea: encontrar un agua que desdibuje la invulnerabilidad y lo haga sentirse vivo de nuevo. Cuando es rasgado por un árbol, se da cuenta de lo feliz que es al ser mortal de nuevo.

Este gesto contemporáneo mostrado por el escritor argentino es defendido como estandarte, por ejemplo, de la filosofía posthumanista: ${ }^{2}$ querer

Ver Mariano Rodríguez, Mesa redonda: "Cuerpo y tecnología a partir de Nietzsche. Pensar lo posthumano", Universidad Complutense de Madrid, Seminario Nietzsche Complutense, https://www. youtube.com/watch?v=zwtnpUonMwI, fecha de consulta: 15 de octubre de 2018. 
borrar la condición humana sufriente y, por lo tanto, anular todo pathos. Esto formó parte del diagnóstico mostrado por Kierkegaard en su obra, a través de diversos personajes conceptuales que teatralizan fragmentariamente ${ }^{3}$ conceptos como: pasión, angustia, desesperación, temor y temblor, duda, aislamiento, salto y nivelación. De esta manera, ironiza el orden establecido y traza un camino edificante que abone al individuo para que, frente a sí mismo, tome la decisión de elegirse, llevando una vida apasionada y de significación, pese a las adversidades y el sufrimiento.

El ensayo "El reflejo de lo trágico antiguo en lo trágico moderno" sale a la luz en el invierno de 1843, abre con espíritu hegeliano, señalando que el desarrollo histórico yace bajo el concepto de lo trágico: pese a que el mundo cambie, lo trágico siempre será lo trágico. El esteta A entiende la acción trágica como aquella acción humana en la cual están en juego "poderes en conflicto que se mantienen mutuamente a raya a tal punto que la acción resulta imposible para el individuo". ${ }^{4}$

Empero, afirma, hay una diferencia esencial entre lo trágico antiguo y lo trágico moderno, que al final se integra y muestra lo trágico. Para introducir el terreno de lo trágico, el esteta A señala dos aspectos de crítica cultural de la época: la duda y el aislamiento ${ }^{5}$ que socavan la existencia,

3 El esteta A reconoce en el ensayo que "lo característico de todo esfuerzo humano en pos de su verdad es ser fragmentario [...] y la riqueza de la individualidad depende justo de su fuerza en la 'disposición fragmentaria' [...] así denomina a su tendencia un ensayo en la tendencia fragmentaria o el arte de escribir documentos póstumos” y como se verá, la disposición fragmentaria se relaciona con lo paradójico.

4 Søren Kierkegaard, O lo uno o lo otro, Un fragmento de vida I, Begonya Saez y Darío González, trad. (Madrid: Trotta, 2006), 180-181.

5 En el texto de La época presente Kierkegaard desarrolla otras características de esta crítica cultural como el desapasionamiento producto del exceso de la reflexión sin acción; y la nivelación, es decir, ser masa y no singularizarse como individuo, así como toda clase de cálculos y consideraciones para que no suceda nada. Dice, son escasas la acción y la decisión: "No queda ningún héroe, ningún amante, ningún pensador, ningún caballero de la fe, nadie magnánimo, ningún desesperado...” 
debilitándola y dejándola sin apoyo. Estas dos categorías trágicas modernas son las que guían todo el desarrollo del estudio firmado con seudónimo. ${ }^{6}$

El análisis del aislamiento es la visión crítica del esteta $\mathrm{A}$, puntualiza Stewart, basada en el planteamiento hegeliano de que la época moderna abandona lo trágico y se dirige hacia lo cómico: "Es la concepción de Hegel de lo cómico la que forma la base de la visión crítica de A de que 'toda la época está trabajando más hacia lo cómico [desde] el aislamiento gana cada vez más ventaja"' ${ }^{7}$ De esta base parte el esteta A, muestra su análisis durante todo el ensayo al tiempo que desarrolla y compara las categorías de la tragedia antigua y la tragedia moderna, para señalar que el aislamiento, en parte, se funda en la comprensión del individuo, la cual tiene su reflejo en la constitución y existencia del mismo. Señala, por ejemplo, que en la Antigüedad el surgimiento de las asociaciones se lee como signo de la disolución del Estado, y ésta como pérdida de la responsabilidad del individuo. Ha sido aflojado el lazo de lo político y de lo que daba fuerza a la religión, pues se ha renunciado a la responsabilidad; todos quieren mandar, pero sin tener la responsabilidad, esto provoca que la subjetividad se haga valer como número, volviéndola aislada y cómica. "Cuando uno se imagina estos poderes enfrentados, incapaces, empero de abordarse mutuamente, porque uno evita indefectiblemente al otro [...] lo que propiamente mantiene al Estado unido está disuelto, pero el aislamiento a que da lugar es naturalmente cómico, estribando lo cómico en que la subjetividad quiere hacerse valer como mera forma". ${ }^{8}$ El Estado ya no es signo de comunidad construida por los individuos; sin la responsabilidad no me ligo a mí mismo ni a los otros.

El esteta A inicia con Aristóteles, quien atribuía lo trágico al raciocinio, al carácter y al telos. Las condiciones de lo trágico en la Antigüedad

Kierkegaard, O lo uno o lo otro, 161-162.

Jon Stewart, Kierkegaard's Literary Figures and Motifs, tomo I, traducción de Berenice Jasso (Nueva York: Ed. Routledge Tylor \& Francis Group, 2016), 56.

Kierkegaard, O lo uno o lo otro, 162. 
poseían mayor pasividad, ya que no se cultivaba el diálogo hasta convertirlo en reflexión; El esteta A vislumbró que lo fatal se puede asimilar mediante la reflexión y la piedad, esto se desarrollará más adelante. El individuo griego se movía libremente y se sostenía sobre las determinaciones sustanciales: el Estado, la familia y el destino, las cuáles constituían lo fatal. El individuo no estaba aislado, mientras que el hombre moderno sí lo está, y por ello no tiene sustento.

En consecuencia, en la tragedia moderna la caída del héroe no es un padecimiento sino una obra, ya que carece de un proscenio épico. Para Aristóteles, la culpa trágica requiere que el héroe caiga en error y la culpa de su acción sea un intermedio entre actuar y padecer.

Así, cuanto más reflexivo es el individuo la culpa es más ética, pero si el individuo no está en posesión de una culpa trágica, se suprime el interés estético y el individuo es vil. El esteta A ve en ello el malentendido de su época, al transustancializar lo fatal en individual, se borra el pasado del héroe y se le imputa todo; es el esfuerzo equivocado de su tiempo y lo que lo hace cómico. Esta transustancialización aísla al individuo. De esta manera, el esteta A dibuja una cierta dialéctica entre la comprensión y la existencia, pues la transustancialización se lleva a cabo a partir de un malentendido. "Por eso, está claro que se trata de un malentendido de lo trágico cuando nuestro tiempo se esfuerza por facilitar la transustancialización de lo fatal en individual y en subjetividad". ${ }^{9}$ Coincido con Stewart en esta exégesis, mientras A dice: “ 'Me abstendré de cualquier profecía de que esto es lo que exigen los tiempos', su claro objetivo es corregir el exceso lírico y el malentendido cómico de la época. Él tiene la intención de hacerlo 'de tal manera que lo verdaderamente trágico se haga evidente', en mi opinión, eso está bastante en desacuerdo con Hegel." ${ }^{10}$

10 Stewart, Kierkegaard's Literary Figures and Motifs, tomo I, 56. 
Curiosamente La época presente, obra de 1843 firmada por Kierkegaard, es un breve texto de crítica cultural en el cual replica la presencia de este malentendido de lo trágico, pero respecto a los hombres de excelencia: "los hombres de excelencia pasarán a actuar sin autoridad. Serán los agentes secretos del divino gobierno, los irreconocibles. Son irreconocibles en el sentido de que la época de los héroes ha pasado. Esto no significa que no haya individuos excepcionales". ${ }^{11}$

Kierkegaard señala que los hombres excepcionales son invisibles e irreconocibles a los ojos de la sociedad de su tiempo. Igualmente, el esteta A dice que el individuo moderno no reconoce ni asimila lo trágico. Además, cuando se quiere hacer valer lo trágico en el contorno de aislamiento se obtiene mal y vileza, porque falta la ambigua inocencia y la sustancialidad.

Continuando con el énfasis, el esteta A ejemplifica en la conciencia general: un individuo cuya estirpe y avatares de la infancia lograrán perturbarlo hasta forzar su caída. La modernidad, en cambio, no lo notaría, pues aplica otra medida al perder lo trágico y ganar desesperación. Entonces, no es que lo trágico no exista, sino que para la época moderna lo trágico - tejido de lo fatal y lo individual- es invisible e irreconocible, ha transustancializado lo fatal en individual. Sin embargo, al abandonar lo trágico y tender hacia lo cómico mediante el aislamiento, cualquier personalidad se vuelve cómica. "Cualquier personalidad aislada se vuelve cómica por el hecho de querer hacer valer su carácter casual por encima de la necesidad del desarrollo". ${ }^{12}$

De forma contraria, Žižek, en su obra Antígona, considera que en el ensayo "El reflejo de lo trágico antiguo en lo trágico moderno", el esteta A dice que lo trágico moderno ha dejado de existir y no sólo se ha dejado de comprender:

Søren Kierkegaard, La época presente, Manfred Svensson, trads. (Madrid: Trotta, 2012), 18.

Kierkegaard, O lo uno o lo otro, 162. 
Antígona, uno de los relatos fundamentales de la tradición occidental. El primero en caminar por esta senda fue nada menos que Kierkegaard, quien [...] propuso [...] una Antígona Moderna. El conflicto está ahora plenamente interiorizado: la presencia de Creonte se vuelve innecesaria. Aunque Antígona admira y ama a su padre, Edipo, héroe cívico y salvador de Tebas, sabe la verdad sobre él (el hecho de que asesinó a su padre y se casó con su madre). El problema de Antígona es que no puede compartir ese saber maldito (como Abraham, que tampoco podía comunicar a otros el mandamiento divino de sacrificar a su hijo): Antígona no puede quejarse, compartir su dolor y su pesar. A diferencia de Antígona de Sófocles que actúa (entierra a su hermano y asume su destino), ella es incapaz de actuar, está condenada a un eterno sufrimiento. La insoportable carga de su secreto, de su destructivo agalma, acaba conduciéndola a la muerte, el único medio que le permite encontrar la paz, dado que no puede buscarla en la simbolización de su dolor o en la comunicación de su pesar. Kierkegaard insiste en que esta situación ha dejado de ser trágica (del mismo modo que ha dejado de serlo la figura de Abraham). ${ }^{13}$

Stewart plantearía que Žižek lee en el esteta A la comprensión de la diferencia de lo trágico antiguo y lo trágico moderno, en donde la escena trágica en la modernidad se vive en el interior, es decir, en el aislamiento. En consecuencia, este trágico conflicto no es menos aparente en la propuesta del esteta A de una Antígona moderna. "Aquí, de nuevo, siguiendo a Hegel, A reconoce que un cambio de interés hacia la experiencia interior de los personajes trágicos distingue la modernidad de la antigüedad" ${ }^{14}$ Sin embargo, el esteta A y Žižek difieren en la interpretación de otro aspecto: como se ha mencionado, Žižek lee que el esteta A considera que lo trágico ha desaparecido y no sólo que su época no lo reconoce. La tarea

\footnotetext{
13 Žižek, Antígona, 10-11.

14 Stewart, Kierkegaard's Literary Figures and Motifs, tomo I, 82.
} 
que el esteta explicita es recuperar y hacer visible lo trágico y combatir lo cómico de la época, pues asegura:

Cualquier individuo por más originario que sea pertenece sin embargo a Dios, a su tiempo, a su pueblo, a su familia, es hijo de sus amigos, sólo en ello radica su verdad, y si pretende ser lo absoluto en toda esta relatividad suya, viene a ser ridículo... Eso mismo sucede con el individio cuando siendo éste arracado, quizás con grandes dificultades, del seno materno del tiempo, pretende ser absoluto en esa inmensa relatividad. Si, por el contrario, desecha esta pretensión para ser relativo entonces posee eo ipso [justamente] lo trágico aun tratándose del más feliz de los individuos; yo incluso diría que sólo es feliz el individuo cuando posee lo trágico. ${ }^{15}$

Entonces, el esteta A aprecia en la recepción y asimilación de lo trágico un tesoro, ya que el coraje y vigor trágicos son tristeza, pero también el remedio cuando uno quiere ganarse de un modo sobrenatural —en otras palabras, cuando uno pretende ser sí mismo—. ${ }^{16}$ Aquí podríamos preguntarnos, ¿qué valor tienen lo trágico y la asimilación de lo trágico para lo religioso kierkegaardiano? Como se deduce, la auténtica subjetividad teje vínculos con todas las dimensiones de su existencia, las asimila e incorpora a su verdad subjetiva. Esto sería para el esteta A responsabilizarse, como condición de posibilidad de la libertad, ${ }^{17}$ pues ahora ya nadie quiere asumir la responsabilidad. $\mathrm{O}$ como queda enunciado en La enfermedad mortal, obra de 1849 firmada por Anti-Climacus, "sólo

15 Kierkegaard, O lo uno o lo otro, 164-165.

16 Lo sobrenatural en Kierkegaard, desde una perspectiva filosófica, es llegar a ser sí mismo, con el soporte de lo infinito y con la posibilidad infinita que devenga en el terreno. Entendemos como el modo más auténtico de libertad propuesta por el danés ser sí mismo, al elegir la posibilidad infinita contenida dentro de su yo.

17 Kierkegaard, O lo uno o lo otro, 161. 
relacionándose consigo mismo y haciendo síntesis se llegará a ser un yo, de lo contrario el yo desespera". ${ }^{18}$

Hasta aquí se ha desarrollado lo trágico como parte del estadio estético, sin embargo, es notable para el trabajo de exégesis, primero, hablar de Johannes de Silentio, seudónimo kierkegaardiano de Temor y temblor quien, al imaginar al Caballero de la fe, lo representa bien sumergido en el mundo. Resalta la relevancia de la asimilación y de los vínculos, por ello se presenta clara la intención del esteta A de poner en crisis la responsabilidad, la duda y el aislamiento de su tiempo, así como pensar en las condiciones de posibilidad que lleven al individuo a reanudar sus vínculos, al tener como horizonte lo religioso. En clave estética kierkegaardiana, devolver la sustancialidad y el proscenio épico a la escena trágica. Segundo, para abonar a esta hipótesis de encontrar cierta dialéctica entre lo estético y lo religioso, se cuestiona por qué al interior del ensayo "El reflejo de lo trágico antiguo en lo trágico moderno" hay un sumario en el cual se describe y relacionan los tres estadios: trágico (estético), ético y religioso, como a continuación se cita:

Lo trágico atesora benignidad infinita, siendo propiamente para la vida humana desde una perspectiva estética la gracia y la clemencia divinas [...] Se trata del amor maternal. Mientras que lo ético es severo y duro, el amor paterno, mientras que lo religioso es la expresión del amor paterno que atesora lo ético pero atenuado por lo que otorga a lo trágico su benignidad: la persistencia. Pero mientras lo estético da tregua, previamente a que la profunda contradicción del pecado se haga valer, lo religioso no da tregua hasta que la contradicción ha sido comprendida en todo su horror. En el instante preciso en que el pecador está a punto de sucumbir al pecado que él mismo se impone se hace patente el consuelo (consuelo religioso, si no es en vano). 
El tiempo lleva buen compás, queriendo hacer al individuo responsable de todo; lo malo es que no con suficiente fervor, de ahí su medianía, presuntuoso para desdeñar las lágrimas de la tragedia y para evitar la clemencia. ¿̨i se eliminan las dos cosas de la vida humana que es la estirpe humana? Trágica tristeza o profunda pena y profunda alegría de la religión. ${ }^{19}$

El gesto trágico del esteta A evoca la necesidad de vincularse con la alteridad, especialmente en momentos de debilidad, de quebrantamiento, sufrimiento, dolor, incluso de falla, pero también en la alegría; ambos momentos constitutivos de la condición humana. El esteta A nombra esta sensibilidad trágica como amor materno y, en la narración de lo religioso, dice, éste ha asimilado lo trágico, con la diferencia de que lo trágico da tregua ante el horror de la contradicción, mientras que lo religioso no, es decir, es persistente. La persistencia es una categoría que refiere temporalidad, supone duración en el tiempo; en la lógica kierkegaardiana es signo de un estado de ánimo alto como la fe, pathos que implica apasionamiento y posibilita la persistencia. Entonces, la intensidad de la subjetividad enmarcada en el pathos y la duración en el tiempo definirán en cierto sentido el modo de existencia, o el estadio en el cual se existe, pues persistir es existir.

Sin embargo, a los ojos del esteta $\mathrm{A}$, en la escena trágica griega el héroe acoge la alteridad apoyándose en la sustancialidad de lo fatal, mientras que, en la modernidad, como se verá más adelante, lo hace mediante la reflexión (angustia) y la compasión, aunque en solitario y, por lo tanto, en el aislamiento. En ambos casos, esta subjetividad trágica no persiste hasta asimilar el horror y la contradicción de la existencia humana, no muestra una voluntad persistente, un temple anímico alto ni una reflexión infinita capaces de metabolizar la contradicción y el horror de la condición humana; en este caso, el esteta A parece sugerir que el indi- 
viduo puede no sólo vincularse sino también asimilar su relatividad, incluida la estirpe con la razón, y afirmarla con el pathos. Empero, se considera que la verosimilitud de la Antígona moderna, elaborada por el esteta A, radica en que representa el momento en que "la reflexión despierta", ${ }^{20}$ de lo contrario se caería la escena trágica como señala el seudónimo. ${ }^{21}$ En el pensamiento kierkegaardiano la reflexión tendrá gran importancia, siempre está en dialéctica con la voluntad del individuo, como se narra en La enfermedad mortal en los siguientes términos: "La conciencia es lo decisivo. En general, la conciencia, es decir, la autoconciencia, siempre es lo más decisivo con relación al yo. Cuanta más conciencia, más yo; cuanta más conciencia, más voluntad; cuanta más voluntad, más yo. Un hombre que no tiene voluntad no es un yo; pero cuanto mayor sea su voluntad, tanto mayor será también la conciencia de sí mismo". ${ }^{22}$

El concepto de voluntad es aludido en el ensayo "El reflejo de lo trágico antiguo en lo trágico moderno" en el pasaje donde cita los tres estadios —estético (trágico), ético y religioso - al hablar del pecado y decir que es el mismo sujeto quien se lo impone, colocándolo como una posibilidad del ejercicio de la libertad. En filología encontramos que la palabra pecado refiere a la transgresión voluntaria de un precepto bueno. Entre los griegos, pecado se decía hamartia y significaba fallo en la meta, no dar en el blanco, desmesura, actitud errónea; mientras que en hebreo era jattáth, errar, no alcanzar una meta, un objetivo, o no dar en el blanco como en griego- Aristóteles comparte esta comprensión y su reflexión

20 Kierkegaard, O lo uno o lo otro, 172.

21 En el ensayo "El reflejo de lo trágico antiguo en lo trágico moderno" cuando el esteta A inicia la caracterización del personaje moderno de Antígona describe que tendrá suficiente reflexión para pertenecer al mundo moderno, pero que la reflexión no debe estar presente en toda su infinitud, o máximo desarrollo, pues de ser así, sustraería por sus propios medios a la mujer de la pena, en cambio cuando la reflexión despierta, ésta no sustrae a la mujer de su pena sino que la instala y muda a cada instante su pena en dolor. Pág. 172.

22 Kierkegaard, La enfermedad mortal, 50. 
sobre la falla en la acción es central en la Poética: encuentra como origen de la acción trágica el raciocinio, el carácter y el fin de la acción —una dimensión racional, una anímica y el telos de la acción-. Estos elementos concentrados se representan en la acción y así se obtienen los géneros literarios como imitaciones de la acción, la cual representa costumbres y modos de pensar. Así, de la imitación de los hombres excelentes surge la épica; de la de los mejores, la tragedia; de los peores, la comedia y de los semejantes, la ditirámbica. ${ }^{23}$

Ahora, en el pensamiento kierkegaardiano, el pecado, igual que Dios, es una elección de la libertad humana, una posición existencial, "ser libre consiste en ser sí mismo”, ${ }^{24}$ y ser sí mismo es elegir la posibilidad más alta. Mientras que el pecado sería renunciar a esta posibilidad. Empero, en la revisión de lo trágico, el esteta $\mathrm{A}$ advierte que el pecado no es un elemento estético, sino más bien ético. La falla trágica se compone de ambigua inocencia, del pecado original o de la sustancialidad que en el esteta A se interpreta asociada al problema de la trasmisión del pecado mediante la categoría de estirpe, que se desarrollará al deconstruir el nombre de Antígona.

Respecto a la duda, como se mencionó al inicio, es una de las dos categorías de crítica cultural del ensayo de estudio, con las que revitaliza lo trágico moderno. En la revisión del texto, no se encuentra un desarrollo explícito del tema, lo nombra como parte de lo trágico moderno, pero no es la condición de su Antígona moderna. Este tema está presente en Temor y temblor, por el momento sólo es posible conectar la duda con el aspecto temporal del temple anímico trágico, mediante la categoría de tregua ya que, si buscamos el significado de esta última, descubrimos que

23 Ver Aristóteles, El arte poética, José Goya y Muniain, trad. (Buenos Aires: 1948), 9-11 http://www. traduccionliteraria.org/biblib/A/A102.pdf.

24 Søren Kierkegaard, Migajas filosóficas o un poco de filosofía, Rafael Larrañeta, trad. (Madrid: Trotta, 2007), 32. 
es la suspensión temporal de una lucha. En paralelo, la duda refiere a la vacilación o falta de determinación ante varias posibilidades de elección. Ambas presuponen intermitencia en el tiempo para llevar a cabo la acción y, por tanto, apelan al aspecto volitivo; justamente en La época presente refiere Kierkegaard que ya no hay acciones. Por su parte, la etimología de duda, en latín dubitare, es vacilar entre dos cosas, no determinarse; dubios que alude a incierto, indeciso, y $d u$ del indoeuropeo refiere a lo que está entre dos cosas. En danés, tvivl, duda, y tvivle dudar, ${ }^{25}$ refieren a un estado de incertidumbre, por ello la duda es un tema central en el pensamiento kierkegaardiano, por el diagnóstico cultural que el filósofo de Copenhague elabora. Para él la duda es deseable antes de llegar a una decisión existencial definitiva, incluso podría tener cierta presencia en la existencia, pero no como estado de ánimo permanente, pues la constante vacilación socava la existencia.

Como se ha señalado, en la fenomenología de la Antígona moderna del esteta A, la duda no está presente en su estado de ánimo. Más bien, la acción de Antígona está configurada por el momento de vida y el desarrollo alcanzado, el tiempo la toma por sorpresa, no tiene tiempo, es un cuerpo sin tiempo. Así lo sugiere Elena Trapanese en su lectura de la Antígona de María Zambrano, ${ }^{26}$ coincide con el personaje del esteta $\mathrm{A}$ al representarla en el momento en que da inicio la reflexión de la subjetividad.

Otro aspecto presente en este análisis de lo trágico es que, en la Antigüedad, el individuo trágico afirma la estirpe y las circunstancias vitales con el pathos de la piedad; mientras que en la modernidad este pathos parece haberse perdido en lo colectivo, aunque la Antígona moderna lo recupera. La naturaleza de la acción de este personaje moderno implica

25 Christian Molbech, Dansk Ordbog, indeholdende det danske Sprogs Stammeord, vol. 2 (Copenhague: Gydendal, 1859), 1287-1289.

26 Elena Trapanese, "Lecturas de Antígona o de la ciudad inclinada", Las torres de Lucca, vol. 7, núm. 12 (enero-junio de 2018), 112. 
una afirmación que se buscará comprender, para ello se retomarán las siguientes nociones. La primera, contenida en el ensayo analizado: lo fragmentario, al sostener que el esfuerzo humano en pos de la verdad es fragmentario y la riqueza de una individualidad viene de su capacidad de ser de esta manera: la capacidad de comprender, hacer, afirmar y ser, a partir de fragmentos de certeza, y no posponer una decisión hasta tener una narración completa y acabada, que no se logrará.

Para abonar a esta exégesis, Judith Butler en Los sentidos del sujeto trabaja la formación del sujeto, su condición, su vulnerabilidad e impresionabilidad. Dedica un capítulo a Kierkegaard para hablar de la desesperación especulativa:

La crítica que Kierkegaard dirige contra Hegel apunta, principalmente, al fracaso de toda filosofía reflexiva para explicar aquello que excede a la propia reflexión: la pasión, la existencia, la fe [...] la pretensión de aportar un relato completo del conocimiento de la realidad [...] por el contrario [...] valorando la pasión y la existencia frente a la reflexión y en último término el lenguaje [...] Kierkegaard se opone a Hegel, pero se trata de una oposición vital $[\ldots]$ construyendo su noción de individuo en los límites del discurso. ${ }^{27}$

Butler visualiza esa condición fragmentaria develada por Kierkegaard y su ironía ante el sistema hegeliano mediante la categoría de desesperación, pues señala que esta última rompe la posibilidad planteada por Hegel de lograr hacer una síntesis armoniosa para conocerse a sí mismo (dotarse de una identidad) y convertir a la alteridad en hogar, tras cada intento:

Se percata de su fracaso al no poder integrar cierta dimensión del yo o del mundo, que pretende aunar en una unidad sintética. Aquello que no lo- 
gra abarcar retorna acosado y minando la relación mediadora que acaba de articular [...] cada fracaso plantea una tarea nueva y aún más sintética al sujeto que emerge de la reflexión [...] aquello que nunca puede llegar a sistematizarse, aquello que impide y se resiste a la reflexión es decir, su propia existencia y sus pasiones constitutivas y excluyentes: la fe y la desesperación [...] la desesperación es una disonancia, una imposibilidad de mediación [...] Kierkegaard se enfrenta a Hegel con la mayor eficacia a nivel estilístico, puesto que lo que busca comunicar son los límites del lenguaje, para comprender lo que significa el individuo. ${ }^{28}$

Butler dice, además, que la tarea del yo, según Kierkegaard, tiene dos caras indisolubles: la de ser autoconstituyente y a la vez derivado. El yo se relaciona consigo mismo y así se relaciona con otro que, en la temporalidad, debe ser previo a él, por tanto, ese otro debe ser infinito. El yo también participa de la infinitud pero está determinado, corporeizado, lo cual significa que todo yo particular es tanto infinito como finito; por ello convive con una paradoja irresoluble, la cual dice Butler, siguiendo a Kierkegaard, sólo puede vivirse, no superarse. El fracaso de la mediación enfatiza el carácter paradójico de la existencia. Stewart coincide en este análisis, al argumentar que el esteta A se separa de Hegel, porque Hegel entiende la catarsis de la tragedia como reconciliación, mientras que el esteta considera que lo trágico representa una tensión irreconciliable:

Si bien estoy de acuerdo con la opinión de que el ensayo de A depende directamente de Hegel, sostengo que las dos visiones están en desacuerdo en la medida en que lo trágico, para Hegel, significa reconciliación, mientras que para A lo trágico representa una tensión irreconciliable, la lucha ambivalente entre lo épico y lo trágico, componentes líricos del arte trágico. ${ }^{29}$

28 Butler, Los sentidos del sujeto, 147-150.

29 Stewart, Kierkegaard's Literary Figures and Motifs, tomo I, 55. 
Volviendo a Butler, se interpreta que el individuo pensado por los seudónimos del esteta A y Johannes de Silentio debe librar la batalla de afirmar su yo de modo paradójico. ${ }^{30}$ Por tanto, la afirmación kierkegaardiana es una afirmación paradójica. En el caso de Antígona, al ser culpable mediante la piedad y al mismo tiempo no serlo. De ahí que el individuo tiemble ante el horror de verse frente a la paradoja de la existencia y al ser la paradoja misma. Desde esta mirada, el pathos, capaz de mantener la persistencia de la afirmación paradójica, son la fe y el amor. Como estado de ánimo más alto, este pathos, en principio, es capaz de soportar el pavor del absurdo y lo paradójico de la existencia y asimilarlo. En contraste, el héroe trágico da tregua ante el horror; la escena trágica de "El reflejo de lo trágico antiguo en lo trágico moderno" muestra y cifra en la representación la condición humana paradójica, que tiene la posibilidad de avanzar mediante la asimilación y la persistencia.

En consecuencia, la acción trágica del esteta A es el momento en que el individuo se vincula y metaboliza su estirpe y sus circunstancias vitales, cada individuo debe plantearse su renacimiento:

$\mathrm{Si}$, en cambio, uno se propone pensar en un renacimiento de lo trágico antiguo, es necesario que cada individuo se pare a pensar su propio renacimiento, no sólo en sentido espiritual, sino sobre todo en el sentido del seno materno de la familia y de la estirpe. La dialéctica que pone en contacto al individuo con la familia y la estirpe no es una dialéctica subjetiva, pues ésta suspende precisamente el contacto y al individuo fuera del contexto: es una dialéctica objetiva. Es en esencia la piedad. ${ }^{31}$

Esta asimilación o renacimiento, como lo nombra el esteta A, soslayaría dos de los problemas de la acción trágica: el aislamiento y la transmisión

\footnotetext{
30 Ver Butler, Los sentidos del sujeto, 156-159.

31 Kierkegaard, O lo uno o lo otro, 177.
} 
del pecado. Esta última cuestión fue referida por Steiner en su obra $A n-$ tígonas al repasar la lectura kierkegaardiana:

Las observaciones preliminares sobre el drama trágico antiguo y el moderno hacen evidente que Kierkegaard, lo mismo que San Agustín y que Pascal, se debate con la paradoja de la "inocente culpabilidad", con la paradoja del pecado original en el alma y en la carne del individuo. El cristianismo y la modernidad reflexiva dieron a esta paradoja una visibilidad negada a la "ingenuidad griega", a la primitiva idea de la condenación predestinada del héroe. Kierkegaard halla en las relaciones de su Antígona con Edipo una realización peculiarmente gráfica y concentrada (el término que usará después es "encarnación") de la fatalidad hereditaria en el antiguo sentido y de la aprehensión reflexiva de esta fatalidad en los modernos. Semejante lectura promete intuir el misterio de la transmisión del pecado de padres a hijos, una transmisión negada en última instancia por la promesa de la salvación que hizo Cristo, pero no por ello menos existencialmente activa en el género humano. Es innegable que en Kierkegaard pesaba el terror de una específica herencia de pecaminosidad, de aquello que Rehm llama "una bendición negativa”. Pero la relación Antígona-Edipo, tal como la pinta Kierkegaard, es representativa de una clásica paradoja teológica y de las consecuencias espirituales y psicológicas de esa paradoja en una escala mucho mayor y mucho más objetiva que la de la crisis privada. ${ }^{32}$

Kierkegaard, en voz del esteta A, puntualiza la transmisión del pecado, simbolizada en lo trágico mediante la categoría de estirpe que, como lee Steiner, se desarrolla con dimensión psicológica en la angustia, continúa en la visión butleriana ${ }^{33}$ como precariedad, en la visión agambeniana ${ }^{34}$

32 George Steiner, Antígonas, Alberto L. Bixio, trad. (Barcelona: Gedisa, 2013), 77.

33 Judith Butler, El grito de Antígona, Esther Oliver, trad. (Barcelona: El Roure Editorial, 2001), 108.

34 Byung-Chul Han, Psicopolítica, Alfredo Bergés, trad. (Barcelona: Herder, 2014), 40-41. 
como hominies sacri y está presente en las interpretaciones psicoanalíticas que hacen exégesis fenomenológica de los efectos psíquicos de transmisión generacional: ${ }^{35}$

Dice Freud: "Nos es lícito entonces suponer que ninguna generación es capaz de ocultar a la que sigue sus procesos anímicos de mayor sustantividad", por lo que así se introduce la cuestión de la transmisión entre generaciones ¿Cómo se involucran las nuevas generaciones con lo sucedido con las anteriores? ¿Cuáles son los procesos elaborativos que cada sujeto puede realizar con aquello transmitido? Por su parte Kaës refiere la noción de trabajo psíquico de la transmisión entendiéndolo como proceso y resultante de ligazones entre aparatos psíquicos y las transformaciones operadas por dichas ligazones". Subraya la diferenciación entre lo que es transmitido y aquello que es recibido y cómo estos elementos son transformados por las nuevas generaciones. Cada sujeto metaboliza, reinscribe e interpreta el legado. ${ }^{36}$

Esta idea de la transmisión del pecado planteada por Kierkegaard mediante el esteta A con la categoría de estirpe, y la posibilidad del individuo de asimilar lo transmitido, la desarrolla desde las raíces anímicas

35 En el libro de Infancias, Gisela Untoiglich analiza los efectos psíquicos producidos por la transmisión generacional, respecto de algunos hechos sociales en México y Argentina: "Considero fundamental que aquellos que nos ocupamos de la salud mental en Latinoamérica nos interroguemos acerca de los efectos del terrorismo de Estado a lo largo de las generaciones en toda la región, ya que éste no es problema de un grupo particular (los 30000 desaparecidos en Argentina y sus familias, los torturados, los muertos o los muertos de Ayotzinapa), sino que nos atańe como colectivo social. Los efectos y las responsabilidades de estos hechos continúan teniendo consecuencias. En la situación argentina, hasta que el último nieto no sea recuperado, habrá familias que vivirán con el vacío de sus seres amados y habrá sujetos que desconocerán su identidad y los efectos de estos delitos de lesa humanidad se transmitirán a través de las distintas generaciones.

36 Liora Stavchansky y Gisela Untoiglich, Infancias, entre espectros y trastornos (Ciudad de México: Paradiso editores, 2017), 208-209. 
que provoca la tragedia. Para la revisión de la estirpe como una dimensión de lo trágico en Antígona, retoma a Aristóteles, para afirmar que en la Antigüedad la compasión es el estado de ánimo que corresponde a la culpa trágica; luego lo compara con Hegel, quien creía que la verdadera compasión es aquella simpatía para con la también ética justificación de quien padece. En la tragedia antigua, dice el seudónimo, la pena es más profunda, y el dolor menor; mientras que en la moderna, el dolor es mayor y la pena menor. Ya que el dolor denota una reflexión acerca del sufrimiento que la pena no reconoce, en la modernidad el dolor es mayor. Además, el dolor más amargo es el arrepentimiento, mas éste tiene fondo ético, no estético, porque goza de transparencia de toda la culpa, pero justo porque ello, no es estético.

El esteta A ve el contraste con su tiempo, al perder las determinaciones sustanciales - familia, Estado y linaje- pierde la compasión, pues abandona al individuo, y éste se convierte en único creador de la acción: es su culpa, su pecado, su dolor y su arrepentimiento, éstos lo instalan en el aislamiento. En suma, la tragedia moderna pierde el interés trágico, pues el poder de donde proviene el sufrimiento ha extraviado su significado; así, el espectador ya no siente compasión y ésta es, tanto en sentido subjetivo como objetivo, la que expresa propiamente lo trágico. ${ }^{37}$

La acción trágica contiene siempre un componente de padecimiento y el padecimiento trágico un componente de acción; lo estético estriba en la relatividad. Es decir, en vincularse con toda esa relatividad, mediante la reflexión, la piedad y la compasión con la estirpe y el resto de las circunstancias vitales. Contrario a ello, la identidad de una acción absoluta y un padecimiento absoluto superan las fuerzas de lo estético y pertenecen a lo metafísico. ${ }^{38}$ 
Para el esteta A la culpa trágica es culpa original, al igual que el pecado original es una determinación sustancial, esto ahonda la pena. La culpa original lleva consigo una contradicción interna: ser culpa y, sin embargo, no ser culpa. Aquí lo paradójico es afirmarlo. El vínculo mediante el cual el individuo viene a ser culpable es justamente la piedad; la pena que contrae tiene anfibología estética. La piedad será entonces la dialéctica mediante la cual el esteta A entienda que el individuo hace a un lado el aislamiento respecto a toda su relatividad para vincularse con la estirpe. ${ }^{39}$

\section{La Antígona moderna kierkegaardiana representada mediante la reflexión, la angustia, el amor como estado de ánimo y la acción trágica sin sustento}

Una vez que Kierkegaard describre las diferencias entre lo trágico antiguo y lo trágico moderno inicia la representación de su Antígona. Del personaje analizaremos la angustia como reflexión, el nombre, el amor estético como estado de ánimo y su acción sin sustento.

El esteta A despliega la representación de su Antígona:

Así, pues, acercaos a mí queridos $\Sigma v \mu \pi \alpha \rho v \varepsilon \rho \omega \mu \varepsilon ́ v o$, circundadme ahora que entrego a mi heroína al mundo, ahora que proveo a la hija de la pena con la dote del dolor. Ella es obra mía y, sin embargo, su contorno es tan indefinido, su hechura tan nebulosa, que cualquiera de vosotros puede enamorarse de ella y podría amarla a su manera. Ella es mi criatura, sus pensamientos son mis pensamientos y, sin embargo, es como si, descansando yo a su vera en una noche de amor, ella me hubiese confesado su más íntimo secreto,

39 Kierkegaard, O lo uno o lo otro, 168-169 
que lo hubiese expirado en mi brazo y, con él, su alma, y que en ese mismo momento ella se hubiese transformado ante mí, que hubiese desaparecido de modo que su realidad se dejase sólo rastrear en el estado de ánimo persistente, en lugar de suceder todo lo contrario, que ella se generase en mi estado de ánimo y ganase así realidad. Le pongo la palabra en la boca y, sin embargo, se me antoja que abuso de su confianza, se me antoja que ella me reprocha a mis espaldas y, sin embargo, es todo lo contrario, en su secreto, ella se hace indefectiblemente más y más visible. Ella es propiedad mía, mi propiedad legal, y, sin embargo, en ocasiones es como si yo me hubiese introducido a traición y a hurtadillas en su confianza, como si hubiese de vigilar sus pasos tras de mí y, sin embargo, es todo lo contrario, yace indefectiblemente ante mí e, indefectiblemente, sólo se constituye en cuanto la expongo. Se llama Antígona. Conservaré ese nombre de la antigua tragedia a la cual me adscribiré por completo aun cuando todo de otro lado viene a ser moderno. Antes, con todo, un comentario. Me sirvo de una figura femenina porque estoy convencido de que una naturaleza femenina vendrá que ni pintada para mostrar la diferencia como mujer dispondrá de la suficiente sustancialidad para que la pena se muestre, pero como miembro de un mundo reflexivo dispondrá de la suficiente reflexión para obtener dolor. Para obtener la pena es preciso que la culpa trágica oscile entre culpa y candor y aquello en virtud de lo cual la culpa trasciende a su conciencia siempre debe ser una determinación de la sustancialidad; pero como para obtener dolor es preciso que la culpa trágica ostente aquella indeterminación, la reflexión no debe estar presente en toda su infinitud pues, de ser así, ésta sustraería por sus propios medios a la mujer de su culpa, ya que la reflexión en su infinita subjetividad, no puede permitir que el componente de la culpa original que otorga la pena se mantenga en pie. Cuando, en cambio, la reflexión despierta, ésta no sustrae por sus propios medios a la mujer de la pena, sino que la instala en ella y muda a cada instante su pena en dolor. ${ }^{40}$ 
Aquí vemos que el esteta A representa a Antígona como personaje conceptual, cifra en ella la condición humana paradójica al ser culpable y al mismo tiempo no serlo. En la Grecia antigua, la subjetividad no estaba suficientemente reflejada para escuchar al coro y establecer un diálogo que elevara el desarrollo de la conciencia y la asimilación de lo fatal. En cambio, en lo trágico moderno, su heroína simboliza el momento en que la reflexión despierta, es decir, es el inicio del desarrollo de la reflexión y, con ella, de la angustia. La facultad no está en su máxima potencia y así debe permanecer. En palabras del esteta A: "la reflexión no debe estar presente en toda su infinitud para que la escena trágica se sostenga". ${ }^{41}$ Esto permite que la pena trágica de Antígona se mantenga en pie, de lo contrario, se sustraería de ella. Pero es la angustia la que, en su ambigüedad, le devela a su estirpe y, con ella, su culpa trágica. Antígona ve en la herencia de su linaje y la potencia de su angustia reflexiva un tesoro, el cual, además, la mantiene siempre alerta. La considera un tesoro pues, interpretamos, es también la conciencia de la condición humana: de la posibilidad de falla, la contingencia, la posibilidad de ser afectado, del sufrimiento y lo paradójico; aunque por ser un estadio estético se comprende con ambigüedad. Esta escena de angustia y comprensión se vive en el aislamiento de la época, la descripción es clara: "Tampoco ella pertenece a este mundo en el que vive, y por más que su vida está en flor y es sana, su vida en sentido propio es clandestina; asimismo, aunque viva, en otro sentido está muerta; esta vida es silenciosa y recóndita, el mundo no oye un suspiro, pues sus suspiros se esconden en la clandestinidad de su alma". ${ }^{2}$

Ahora, en lo referente al nombre de Antígona se seguirá el problema de la transmisión del pecado que el esteta A titula como estirpe, para conectarlo con la lectura que Žižek hace en su obra Antígona, en la cual decons-

$41 \quad$ Kierkegaard, O lo uno o lo otro, 172.

42 Kierkegaard, $O$ lo uno o lo otro, 174-175. 
truye el nombre, para considerar una posibilidad hermenéutica de lo que puede representar el gesto de esta heroína trágica y su contemporaneidad:

Por la ambigüedad del nombre Antígona, que podemos interpretar como inflexible (a partir de anti-y-gon/-gory rincón, curva, ángulo) pero también como opuesta a la maternidad o en lugar de una madre, a partir de la raíz gone, aquello que genera (como el -gony de teogonía). Es difícil resistir a la tentación de plantear un vínculo entre ambos significados: ¿acaso no es el ser madre la forma elemental de subordinación de la mujer, con lo que la inflexible actitud de Antígona ha de entrañar el rechazo de la maternidad? Irónicamente en el mito original de Higinio Antígona era madre. ${ }^{43}$

Butler coincide con Žižek en su obra El grito de Antígona, al indicar que el nombre podría interpretarse como "antigeneración” ${ }^{44}$ y resistencia. A este respecto, Butler, siguiendo a Lacan, apunta que la maldición del padre se transmite por medio de las palabras: "La maldición establece una temporalidad para esta acción que precede a la propia maldición. Las palabras trasladan al futuro lo que ya ha estado ocurriendo siempre". ${ }^{45}$ Steiner también hace alusión a este rasgo de resistencia en un pasaje de su estudio de la Antígona de Hölderlin: "Desde mi niñez aprendí a ser obediente; primero con mis padres, luego con una divinidad. Y en la obediencia mi alma se siente libre y a sus anchas. Pero ni en Argos ni aquí aprendí a doblegarme ante el craso decreto de un hombre". ${ }^{46}$ Finalmente, el esteta A refiere que Antígona es silencio, para honrar a su padre y a su estirpe, guardando el secreto.

Al hilar las pistas de Žižek, Steiner, Butler y el esteta A podríamos preguntarnos: ¿En qué sentido Antígona se niega a ser madre?, ¿qué se

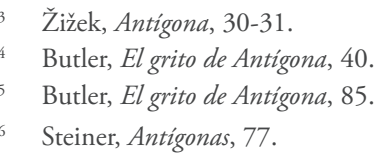


niega a concebir o heredar?, ¿a qué se resiste?, ¿por qué el esteta A la nombra como auténtico vigor materno? Será que, a partir de su profunda compasión y piedad, ama y afirma a su estirpe, pero también se resiste a transmitir el pecado guardando el secreto en lo profundo de su corazón. Y quizá también lo asimile, de esa manera se resiste a reproducir el pecado, esta caída que el esteta A señala: "es el mismo individuo quien se impone el pecado". ${ }^{47}$

Asimismo, Antígona, al interpretarse y no sólo comprenderse, decide ser alumbradora y fuente de amor fraterno, encarna la compasión filial y la universalidad del amor (por eso las numerosas comparaciones que hacen de ella con Cristo). Diversos intérpretes refieren que Antígona abre camino para la revelación, se lee como la capacidad del hombre para encarnar el amor y experimentar el reino de los cielos como estado anímico, como un estado del corazón. No niega ni desprecia la alteridad, sino que la ama y acoge, especialmente en los momentos cuando la vulnerabilidad de la condición humana queda expuesta.

De ahí que Antígona se anticipe: vaticina la posibilidad humana de encarnar el amor. Siguiendo al esteta A, diríamos que el personaje simboliza el amor paradójico, pues devela la posibilidad de ser afectados, pero, al mismo tiempo, tanto en clave kierkegaardiana como nietzscheana, se aprecia la dualidad del amor. Como interpreta el filósofo español Carlos Sancho, respecto al Jesús de Nietzsche, Jesús descubre el amor como sentimiento de poder y como signo de la voluntad de poder. Este afecto expresa el estado de su corazón, y le permite experimentar el reino de los cielos, la eternidad, la felicidad y la divinidad aquí en la Tierra. Desde el amor se relaciona con la alteridad sin caer en una lógica retributiva, una lógica de amigo-enemigo, sin alienarse. ${ }^{48}$ Esta descripción coincide con

Ver Kierkegaard, O lo uno o lo otro, 165.

48 Carlos Sancho, "Moral y religión en la voluntad de poder", Seminario Nietzsche Complutense, Universidad Complutense de Madrid, https:/www.youtube.com/watch?v=t9eFsA2C2Fk. 
la que el esteta A hace del estado anímico de Antígona como señorío: "ella no es en modo alguno una mujer débil o enfermiza, al contrario, es orgullosa y poderosa". ${ }^{49}$

El personaje de Antígona ama desde una condición de poderío, como signo de fuerza; este gesto amoroso de Antígona es de auténtico poder, ampara a la alteridad. Esta actitud es contraria a la fenomenología descrita por el esteta A respecto a la subjetividad moderna, la cual se desarrolla aislada, dudosa, indiferente, irresponsable y, por tanto, cómica; de lo que se deduce, se trata de una subjetividad moderna desamparada. La exégesis devela el vigor materno de la Antígona moderna kierkegaardiana como potencia de asimilarse, establecer vínculos y ser hospitalaria con la alteridad, en especial en momentos de vulnerabilidad. Anouilh representa este gesto en su guión de Antígona:

Antígona, con un suspiro. - Bien. (permanecen un instante sin decir nada, después, ella comienza despacio) Escucha, Hemón.

Hemón. —Sí

Antígona. —Quería decirte esta mañana... el hijito que habríamos tenido... Hemón. - Sí.

Antígona. - Tú sabes, lo habría defendido bien contra todo.

Hemón. - Sí, Antígona.

Antígona. — ¡Oh! Lo hubiera abrazado tan fuerte que él no habría tenido miedo jamás, te lo juro. Ni de la noche, ni de la angustia del pleno Sol inmóvil, ni de las sombras... ¡Nuestro hijito, Hemón! Habría tenido una mamá muy pequeñita y mal peinada, pero más segura que todas las verdaderas madres del mundo con sus pechos verdaderos y sus grandes delantales $[\ldots]^{50}$

49 Kierkegaard, O lo uno o lo otro, 172-173.

50 Jean Anouilh, Antígona, Rodolfo Marcos Turnbull, trad. (Ciudad de México: Herder, 2016), 47. 
Hemón. —...Estoy muy solo, en el mundo está demasiado desnudo[...]

Creonte, se desprende de él. —Estamos muy solos, Hemón $[\ldots]^{51}$

El amor como constituyente del pathos trágico también muestra lo paradójico, pues es por fuerza y debilidad como nace de la recepción y asimilación de la relatividad del individuo, de la estirpe, exponiendo tanto a la condición humana contingente, posible de falla, la condición de ser afectado, como su poderío, nacido de la capacidad subjetiva para vincularse con la alteridad mediante la piedad y el amor:

En una edad más temprana, antes aún de que ella hubiese alcanzado su completo desarrollo, oscuros indicios de este tremendo secreto habían sobrecogido su alma durante escasos momentos, hasta que la certeza la arroja de golpe a los brazos de la angustia. Aquí dispongo ya de una determinación de lo trágico moderno. La angustia es precisamente reflexión y por eso mismo es esencialmente distinta de la pena. La angustia es un órgano mediante el que el individuo se apropia de la pena y la asimila. La angustia es la fuerza motriz mediante la cual la pena se introduce, perforándolo, en el corazón de uno [...] La angustia tiene una doble función: en parte es el movimiento que consiste en pulsar la pena sin cesar y que en virtud de este tanteo la descubre, pues circunda la pena. O bien la angustia se da de repente y fija toda la pena en un único ahora, aunque de tal modo que éste ahora se disuelve al instante en una sucesión. La angustia es en este sentido una auténtica determinación trágica $[\ldots]$ es una determinación de la reflexión queda de manifiesto en la lengua misma, pues yo digo siempre "angustiarse por algo" [...] la angustia siempre contiene una reflexión sobre el tiempo, pues yo no puedo angustiarme ante el presente sino sólo por el pasado o por el futuro, pero lo pasado y futuro, opuestos así, mutuamente, de modo que el carácter de lo presente desaparece, son determinaciones reflexivas. La pena griega, por el contrario, 
al igual que la vida griega por entero, tiene el carácter de lo presente, y por ello es más honda, pero el dolor menos. Por ello, la angustia pertenece en esencia a lo trágico moderno. Por eso es Hamlet tan trágico, porque presagia el crimen materno. ${ }^{52}$

La angustia como reflexión es la fuerza constitutiva de la subjetividad frente a la paradoja estética, ser culpable y al mismo tiempo no serlo, mediante la cual el individuo se hace consciente de la culpabilidad trágica con la reserva de su ambigüedad. Mediante ella el individuo recibe el legado de su relatividad de modo racional y anímico. Ésta es la dual fenomenología estética de la angustia. A este respecto, Butler señala que Kierkegaard vio el germen de la angustia, el temor y el temblor en Hegel:

En Hegel ese momento, en el que el temor y el temblor son considerados experiencias necesarias para lograr la libertad humana. Podemos encontrar ese momento al final del conocido capítulo de la Fenomenología del espiritu titulado "Señorío y servidumbre". Allí, el siervo, que era propiedad del señor, se libera de su propia esclavitud. En este instante esperaríamos encontrar la extenuante celebración de la libertad, pero en cambio nos topamos con el miedo aplastante del siervo. Consideremos la descripción del siervo emancipado en la Fenomenología del espiritu de Hegel como un ejemplo de temor y temblor producido por la experiencia de la libertad humana desatada de la autoridad [...] Si la conciencia se forma sin pasar por el temor primario absoluto, sólo es un sentido propio vano, pues su negatividad no es la negatividad en sí, por lo cual su formarse no podrá darle conciencia de sí como esencia. Y si no se ha sobrepuesto al temor absoluto, sino solamente a una angustia cualquiera, la esencia negativa seguirá siendo para ella algo externo, su sustancia no se verá totalmente contaminada por ella. 
Hegel sigue y destaca que si el siervo no ha sido saqueado por el temor hasta lo más profundo de su ser permanecerá una libertad sometida a la servidumbre..$^{53}$

El esteta A muestra que su Antígona tiene suficiente libertad, aunque experimente angustia por el conocimiento del terrible secreto de su estirpe. Posteriormente, esta misma angustia le permite metabolizar y afirmar su herencia. Angustia que vive, pero no supera. Aquí hay otra diferencia en las visiones hegeliana y kierkegaardiana. Butler destaca la agudeza kierkegaardiana en oposición a la visión hegeliana de la fenomenología de la angustia y el temor, así como la relevancia de lo anímico en los movimientos de los personajes conceptuales kierkegaardianos, justo como derivación de un estado de ánimo. Si bien Butler en este pasaje se centra en Abraham, lee la capacidad anímica para metabolizar de los personajes de los tres estadios, por la importancia de mostrar la interpretación del trabajo psíquico, a continuación, se cita en extenso a la filósofa estadounidense:

Kierkegaard no sólo se siente horrorizado ante el sacrificio que la fe exige a Abraham. También le impacta que Abraham recupere a Isaac, que Dios no le exija únicamente un sacrificio, sino que le devuelva aquello que ha perdido y todo ello sin ninguna razón. Además, parece que Abraham no se rebela contra Dios [...] recupera lo finito [...] en virtud del absurdo [...] la fe de Abraham es un prodigio, puesto que no titubea [...] creyó en virtud del absurdo [...] todo cálculo humano ya estaba desechado [...] si la fe marca el límite del pensamiento, si la fe surge precisamente cuando el pensamiento fracasa al intentar comprender que tiene ante sí [...] No se vuelve contra lo finito (Isaac) ni contra lo infinito (Dios), sino que se prepara para la afirmación paradójica de ambos [...] el esteta y el ético no pueden despojarse de 
este terror; están desesperados que se dejan llevar por este terror y se sumergen en el terreno sensible y ético para sofocar la ansiedad que les genera la contingencia humana [...] porque se pueden trazar los movimientos de la fe pero ser incapaz de dar el salto necesario [...] en términos de Kierkegaard, expresar el sublime impulso en el curso terreno [...] en comparación con el caballero de la resignación que sabe sacrificar las cosas infinitas y evitar la desesperación que caracteriza al esteta, así como al ético, pero no sabe cómo afirmar la infinitud que hace que la vida sea completamente absurda. ${ }^{54}$

Es interesante que Butler, al trazar la huella fenomenológica kierkegaardiana, diferencie los personajes mediante la capacidad o incapacidad del esteta, el ético y el religioso, para manejar el terror y afirmar lo infinito y lo absurdo, lo contingente y lo paradójico de la existencia, como distintivo que traza cierta demarcación de los estadios kierkegaardianos. Entonces, la disposición anímica da, en parte, el modo existencial, el estadio en el que se existe, en pensamiento heideggeriano: el Dasein como disposición afectiva. Aquí la contemporaneidad kierkegaardiana inicia el giro afectivo en la modernidad para pensar problemas filosóficos que exceden las explicaciones discursivas, en este caso, para pensar lo trágico. Este enfoque en la filosofía heideggeriana lo apreciamos como planteamiento ontológico en Ser y tiempo en los $\$$ del 29 al 32, así enunciados:

Disposición afectiva y comprender caracterizan como existenciales la aperturidad originaria del estar-en-el-mundo. En el modo del temple anímico, el Dasein "ve" posibilidades desde las cuales él es. En la apertura proyectante de estas posibilidades él ya está siempre anímicamente templado. ${ }^{55}$

54 Butler, Los sentidos del sujeto, 167-177.

55 Martín Heidegger, Ser y tiempo, José Eduardo Rivera, trad. (Madrid: Trotta, 2012), 166-167. 
El Dasein en cuanto comprender proyecta su ser hacia posibilidades. Este comprensor estar vuelto hacia posibilidades, por la repercusión que tienen sobre el Dasein esas mismas posibilidades en tanto que abiertas, es también un poder-ser. El proyectarse del comprender tiene su propia posibilidad de desarrollo. A este desarrollo del comprender lo llamamos interpretación [Auslegung]. En la interpretación el comprender se apropia comprensoramente de lo comprendido por él. En la interpretación el comprender no se convierte en otra cosa, sino que llega a ser él mismo. La interpretación se funda existencialmente en el comprender, y no es éste el que llega a ser por medio de aquélla. La interpretación no consiste en tomar conocimiento de lo comprendido, sino en la elaboración de las posibilidades proyectadas en el comprender. ${ }^{56}$

La disposición afectiva heideggeriana, como parte de la estructura ontológica del Dasein, a nuestra consideración tiene germen kierkegaardiano. Y desde ahí podemos decir que Antígona está ya templada y es desde las posibilidades que es capaz de ver, comprender, interpretar, actuar y ser.

El último aspecto del despliegue anímico de Antígona, es lo que el esteta A dice de su heroína: "Antígona dispone de fuerza, la pregunta no es si ella por su propio bien, para aligerar su pecho, tiene que confiar a alguien su dolor, pues es perfectamente capaz de soportarlo sin sustento". ${ }^{57}$ La frase adverbial de la acción es escandalosa: sin sustento; cuando el esteta ha diagnosticado y combatido durante toda la reflexión del ensayo el aislamiento, para subrayar que lo trágico existe como realidad fenoménica de la condición humana, pero al perderlo, la modernidad intensifica lo trágico por la falta de comprensión, y el desamparo del individuo frente a la fatal condición.

\footnotetext{
56 Heidegger, Ser y Tiempo, 167.

57 Kierkegaard, O lo uno o lo otro, 180.
} 
Aquí, la doble génesis de la angustia que experimenta la Antígona moderna: primero por la constitución trágica de la existencia y su condición paradójica, y segundo por el desamparo epocal, expuesto por el esteta $\mathrm{A}$ mediante la categoría de aislamiento, al no contar con el sostén de las determinaciones sustanciales. La visión derridiana vislumbra la vigencia contemporánea del este diagnóstico:

Al reflexionar que de por sí, la condición humana nos lleva a temblar, y no podemos no temblar frente a ciertas situaciones, situaciones en las que por lo tanto, se debe: aceptar la falla, el fracaso, el desfallecimiento, la amenaza, la duda, el vértigo de la libertad, la experiencia de la asimetría del don del amor infinito versus nuestra finitud, porque de querer actuar tendremos que hacerlo: sin ver, o sin verlo todo; sin saber o sin saberlo todo, sin comprender, o sin comprenderlo todo, y sin saber lo que nos espera. ${ }^{58}$

El temblor, dice Derrida, muestra nuestra vulnerabilidad, y hace temblar la autonomía del yo. Además, subraya el pensador francés en concordancia con Kierkegaard, no sólo temblamos sino el mundo entero tiembla, tiene terremotos y los sufrimos; de hecho, el mundo ya no existe, ya no hay suelo ni fundamentos que lo sostengan, y cuando el mundo ya no existe, debo responsabilizarme del otro y cargarlo, pues el mundo se ha quedado sin fundamentos. ${ }^{59}$ Como lo hace Antígona, que se inclina para dar soporte a su hermano, a su padre y a su amado, pese a su temblor, su angustia y doble desamparo. Butler replica este diagnóstico en su obra: El grito de Antígona: "Antígona es sobrepasada sin haber sido nunca protegida" ${ }^{60}$

Antígona puede representar el gesto de la compasión filial, de la universalidad del amor, de los vínculos. Por ejemplo, para un momento como éste,

58 Derrida, ¿Cómo no temblar?, 23-25.

59 Derrida, ¿Cómo no temblar?, 32-33.

60 Butler, El grito de Antígona, 19. 
en que el covid-19, como apunta Žižek, ha estremecido al mundo mostrando con toda crudeza la vulnerabilidad de nuestra condición humana:

Se nos bombardea precisamente con llamamientos no sólo a no tocar a los demás, sino a aislarnos, a mantener una distancia corporal adecuada. ¿Cuál es el significado de esta prohibición de no me toques? Las manos no pueden acercarse a la otra persona; sólo desde el interior podemos acercarnos unos a otros y eso [...] ningún coronavirus nos lo puede arrebatar. De manera que existe la esperanza de que la distancia corporal incluso refuerce la intensidad de nuestro vínculo con los demás. Es solo ahora, en este momento en que tengo que evitar a muchos de los que me son próximos, cuando experimento plenamente su presencia y la importancia que tienen para mí [...] es difícil pasar por alto la suprema ironía de lo que nos ha unido y ha promovido la solidaridad global se expresen en la vida cotidiana en forma de órdenes estrictas para evitar la proximidad con los demás, e incluso para aislarse. No nos enfrentamos tan sólo con amenazas virales, sino que hay otras catástrofes que asoman en el horizonte o que ya están ocurriendo: sequías, olas de calor, tormentas mortales [...] la respuesta no es el pánico, sino una labor ardua para establecer algún tipo de coordinación global eficaz. ${ }^{61}$

\section{A modo de conclusión}

La obra de Antígona sigue abierta al porvenir para dotarse de nuevos significados, por ahora, desde la reflexión fragmentaria que aquí se ha construido, nos ha develado la comprensión de los límites del lenguaje y de la filosofía para comprender la existencia y la condición trágica del individuo. Ha sido fragmentaria como signo de renuncia a querer expli-

61 Slavoj Žižek, Pandemia, La Covid-19 estremece al mundo, Damià Alou, trad. (Barcelona: Anagrama, 2020), 6-8. 
carla en su totalidad, pues la capacidad explicativa está excedida por la existencia misma. Esta renuncia también significa la confianza en saberes más vastos que la razón.

Antígona, como personaje conceptualmente potente, representa la colisión trágica de la acción humana frente a los principales conflictos: hombre y mujer; individuo y comunidad o Estado; jóvenes y ancianos; vivos y muertos; hombres y dioses. Pero, también, la posibilidad del individuo de tomarse a sí mismo desde la perspectiva del seno materno para plantear su renacimiento, ejercitando la comprensión de sí mismo, de su libertad, del encuentro con la alteridad, todo ello mediante el temple de su disposición anímica. Será esta disposición anímica la que le muestre las posibilidades desde las cuales desplegar el ejercicio de su libertad. Por ello la tarea tan clara de la filosofía kierkegaardiana: edificar al individuo.

Kierkegaard, en voz del esteta A, problematizó la existencia moderna por su falta de fe, pasión y responsabilidad, mediante las categorías de duda y aislamiento, señaló la imposibilidad de existir genuinamente. Presentó un desafío a su época: repensar la construcción de los vínculos, pues de mantener la transustancialización de lo fatal en individual no hay manera de que el individuo llegue a ser sí mismo de modo auténtico, ni que sea capaz de atravesar la existencia; pues, por más originario que sea el individuo, pertenece, a su tiempo, a su pueblo, a su familia y a sus amigos. Este trabajo implica la metabolización de toda su relatividad, un renacimiento de lo trágico en el sentido de la estirpe, en clave del psicoanálisis contemporáneo: crear la oportunidad de reescribir la biografía, dejándose guiar por lo enigmático de su singularidad, la alteridad, la época y la existencia misma, desde una posición tanto apasionada como crítica que resista todo aquello que intente alienarlo.

Absolutizar una narración racional constituye la reducción del mundo y, con ello, de las posibilidades humanas. En última instancia la pretensión contemporánea de querer borrar la condición humana, controlar el azar y el sufrimiento, está impedida por el principio de realidad que, 
de ser plausible, incapacitaría al ser humano de percibir la belleza de la existencia, pues, como han comprendido algunos estetas, la auténtica belleza es el escudo que vela lo terrible, que contiene la unidad completa de la existencia y hace de lo terrible, soportable; no sólo lo hace soportable, sino que nos mantiene en contacto con la vida, dotándonos de una cierta sensibilidad y un estado anímico alto para comprender y afirmar la existencia en su paradójica constitución.

Así, lo trágico muestra en el horizonte la posibilidad y la necesidad de la afirmación paradójica de la existencia, pues sólo puede vivirse más no superarse. Esta tensión paradójica constitutiva del individuo coloca la libertad en la dialéctica de lo temporal y lo eterno, la posibilidad y la necesidad, lo finito y lo infinito, manteniendo la apertura del individuo tanto a la posibilidad de ser afectado, como a lo imposible, la alteridad, el porvenir, el acontecimiento. No es posible ni deseable el absoluto control y la predictibilidad de la existencia, sino mantener la apertura y el enigma.

Por ello, lo estético estriba en la relatividad, que alumbra lo paradójico cifrado en lo trágico, mientras que el momento trágico es también la potencia del amor. Sólo el amor es capaz de transitar, resistir y asimilar lo paradójico. Así, Antígona representa la apertura a la alteridad, la posibilidad de ser afectado, lo paradójico, el poderío, el umbral de lo imposible y el acontecimiento.

En suma, la reflexión sobre el ensayo "El reflejo de lo trágico antiguo en lo trágico moderno" en voz de el esteta A representa también la posibilidad de profundizar la comprensión en torno al desdibujamiento en la conciencia de la condición humana y la sustancialidad, que conduce al individuo moderno y contemporáneo al aislamiento y la desesperación. Diversos estudios hablan de la tendencia actual a la soledad mientras que la depresión es nombrada la discapacidad del siglo XXI, aquí la vigencia kierkegaardiana. El diálogo del esteta A con otros trabajos de Kierkegaard, sus intérpretes, otras versiones de Antígona, Steiner, Žižek, Derrida, Butler y Heidegger ha potenciado el horizonte hermenéutico 
para leer la vigencia de lo trágico en la contemporaneidad; al tiempo de tener mayor conciencia trágica de la indisoluble unidad paradójica de la existencia y del mundo: vida y muerte, placer y dolor, fuerza y debilidad, falla y poderío, eternidad y temporalidad, finitud e infinitud, individualidad y alteridad, razón e instinto, horror y belleza. Esta conciencia se puede vivir desde el desprecio y la desesperación o desde la esperanza, la alegría y el amor sin que esto último represente una falsa conciencia, sino ese arge griego, autodominio y pathos afirmativo de la existencia. Como refiere Derrida, la condición humana nos lleva a temblar, y no podemos no temblar frente a ciertas situaciones, en las que se debe: aceptar la falla, el desfallecimiento, la amenaza, la duda, el vértigo de la libertad; de querer actuar, tendremos que hacerlo: sin ver o sin verlo todo; sin saber o sin saberlo todo; sin comprender o sin comprenderlo todo, y sin saber lo que nos espera. Aun así debemos actuar con pasión y esperanza.

Para finalizar, aun con todo lo planteado parece necesario pensar estas categorías kierkegaardianas a la luz de todos los avances genéticos y tecnológicos que hoy prometen el mejoramiento de todas las capacidades humanas - la condición humana-. Ya existen seres humanos con partes robóticas, como la mano cibernética que científicos alemanes colocaron a un exsoldado en 2006, la cual está conectada a las terminales nerviosas del cerebro y puede transmitir impresiones táctiles al cerebro del propietario. Algunos industriales ya están trabajando en la posibilidad de conectar también el celular al cerebro, por nombrar algunos ejemplos. Así que, en un siguiente trabajo, sería fundamental profundizar en la recepción contemporánea del pensamiento trágico kierkegaardiano y considerar sus categorías a la luz de la inteligencia artificial, la automatización, la ciencia de datos y todo el horizonte que se vislumbra, para problematizar nuevamente la condición humana, pues si algo muestran el enfoque fragmentario y la hermenéutica es que se avanza en comprensión y se puede llegar a niveles muy profundos, pero siempre quedará algo sin develar y por deconstruir. 


\section{Referencias}

Anouilh, Jean. Antígona. Traducido por Rodolfo Marcos Turnbull. Ciudad de México: Herder, 2016.

Aristóteles, El arte poética. Traducido por José Goya y Muniain. Buenos Aires, 1948. Disponible en: http://www.traduccionliteraria.org/ biblib/A/A102.pdf

Butler, Judith. El grito de Antígona. Traducido por Esther Oliver. Barcelona: El Roure, 2001.

. Los sentidos del sujeto. Traducido por Paula Kuffer. Barcelona: Herder, 2016.

Derrida, Jacques. ¿Cómo no temblar? Traducido por Esther Cohen. Acta Poética 30-2, 2009: https://redaprenderycambiar.com.ar/derrida/ textos/temblar.htm.

Eagleton, Terry. Una introducción a la teoria literaria. Ciudad de México: Fondo de Cultura Económica, 1998. Disponible en: https:// estudiosliterariosunrn.files.wordpress.com/2010/08/eagleton-terry-una-introduccion-a-la-teoria-literaria.pdf.

Guerrero, Luis. El individuo frente a si mismo, El pensamiento de Søren Kierkegaard. Estado de México: Porrúa, 2017.

. Qué significa existir? Ensayos sobre la filosofía de Søren Kierkegaard. Roma: IF Press SRL, 2017.

Han, Byung-Chul. Psicopolítica. Traducido por Alfredo Bergés. Barcelona: Herder, 2014.

Hannay, Alastair. Kierkegaard, Una biografía. Traducido por Nassim Bravo Jordán. Ciudad de México: Universidad Iberoamericana, 2010.

Hart, Chris. Doing a Literature Review, Releasing the Social Science Research Imagination. California: SAGE Publications, 2000.

Heidegger, Martín. Ser y tiempo. Traducido por José Eduardo Rivera. Madrid: Trotta, 2012.

Kierkegaard, Søren. El concepto de la angustia. Traducido por Demetrio Gutiérrez. Madrid: Alianza, 2010. 
. La enfermedad mortal. Traducido por Demetrio Gutiérrez. Madrid: Trotta, 2008.

. La época presente. Traducido por Manfred Svensson. Madrid: Trota, 2012.

- Migajas filosóficas o un poco de filosofía. Traducido por Rafael Larrañeta. Madrid: Trotta, 2007.

. O lo uno o lo otro, Un fragmento de vida I. Traducido por Begonya Saez y Darío González. Madrid: Trotta, 2006.

- Poscriptum no cientifico y definitivo a Migajas filosóficas. Traducido por Nassim Bravo Jordán. Ciudad de México: Universidad Iberoamericana, 2008.

. Temor y temblor. Traducido por Vicente Simón. Madrid: Alianza, 2012.

Marshall, Berman. Todo lo sólido se desvanece en al aire, la experiencia de la modernidad. Traducido por Andrea Morales. Ciudad de México: Siglo Xxi, 2011.

Molbech, Christian. Dansk Ordbog. indeholdende det danske Sprogs Stammeord, vol. 2. Copenhague: Gydendal, 1859.

Nietzsche, Friedrich. El nacimiento de la tragedia. Traducido por Andrés Sánchez Pascual. Madrid: Alianza, 2011.

Rodríguez, Mariano. Mesa redonda: "Cuerpo y tecnología a partir de Nietzsche. Pensar lo posthumano”. Madrid: Universidad Complutense de Madrid, Seminario Nietzsche Complutense, https:// www.youtube.com/watch?v=zwtnpUonMwI.

Sancho, Carlos. "Moral y religión en la voluntad de poder". Madrid: Universidad Complutense de Madrid, Seminario Nietzsche Complutense, https://www.youtube.com/watch?v=t9eFsA2C2Fk.

Stavchansky, Liora y Gisela Untoiglich. Infancias, entre espectros y trastornos. Ciudad de México: Paradiso editores, 2017.

Steiner, George. Antígonas. Traducido por Alberto L. Bixio. Barcelona: Gedisa, 2013. 
Stewart, Jon. Kierkegaard's Literary Figures and Motifs, tomo I. Agamemnon to Gaudalquivir. Nueva York: Routledge Tylor \& Francis Group, 2016.

Trapanese, Elena. "Lecturas de Antígona o de la ciudad inclinada", Las torres de Lucca vol. 7, núm. 12 (enero-junio de 2018): 103-124.

Žižek, Slavoj. Antígona. Traducido por Francisco López. Madrid: Akal, 2017.

Žižek, Slavoj. Pandemia, La Covid-19 estremece al mundo. Traducido por Damià Alou. Barcelona: Anagrama, 2020. 